\title{
ANTAGONISTIC EFFECT OF STAPHYLOCOCCUS HYICUS AND STAPHYLOCOCCUS CHROMOGENES EXHIBITED ON STAPHYLO- COCCAL DELTA HEMOLYSIN
}

\author{
B. SKALKA \\ Department of Epizootiology, Microbiology and Immunology, \\ University of Veterinary Science, 61242 Brno \\ Received December 19, 1989
}

\begin{abstract}
Skalka B.: Antagonistic Effect of Staphylococcus hyicus and Staphylococcus chromogenes Exhibited on Staphylococcal Delta Hemolysin. Acta vet. Brno, 60,1991: 61-69.

Staphylococcus hyicus and Staphylococcus chromogenes are able to inhibit hemolytic effect of the staphylococcal delta hemolysin on agar media supplemented with human or sheep erythrocytes. This inhibition takes place even when the effect of delta hemolysin on agars with sheep erythrocytes is potentiated with staphylococcal beta hemolysin. Although less markedly expressed, similar antagonistic effect on staphylococcal delta hemolysin is also found in a majority of strains Staphylococcus sciuri, Staphylococcus lentus and some Micrococcus spp. Other species of coagulase-negative staphylococci have no antagonistic effect on delta hemolysin. A technique of a combined test of hemolytic interactions (CTHI) for a simultaneous assay of hemolytic antagonism and synergism was proposed, which can be used to differentiate $S$. hyicus and S. chromogenes from other novobiocin-sensitive staphylococcal species.
\end{abstract}

Staphylococcus hyicus, Staphylococcus chromogenes, staphylococcal delta hemolysin, antagonistic effect, combined test of hemolytic interactions (CTHI)

In our previous paper (Skalka 1988) we described hemolytic activity of $S$. hyicus and $S$. chromogenes on blood agars with rabbit or human erythrocytes. Hemolytic effects of these two staphylococcal species on agar media supplemented with erythrocytes of various animal origin differed from the data on sensitivity of various erythrocytes to staphylococcal hemolysins alpha, beta, gamma and delta (Dolman 1932; Glenny and Stevens 1935; Smith and Price 1938; Williams and Harper 1947; Marks and Vaughan 1950; Jackson 1962; Jeljaszewicz 1972; Wiseman 1975). In the paper mentioned we were not even able to confirm the descriptions of delta hemolysin production by certain strains of the two staphylococcal species (Hebert and Hancock 1985; Lammler and Blobel 1987; Watts and Owens 1987) or the information on their ability to produce gamma hemolysin (Goodfellow et al. 1987).

The discrepancy between our findings and the descriptions of other authors cited stimulated our continuous study of hemolytic manifestations of the two above-mentioned staphylococcal species, which is the subject-matter of the present paper.

\section{Materials and Methods}

Blood agars

Brain heart infusion agar CM 375 (Oxoid Ltd.) or "basis for blood agar No. 4" (Imuna) were supplemented with $5 \%(\mathrm{v} / \mathrm{v})$ washed sheep or human erythrocytes.

Tested Strains

The set of tested strains of staphylococci included $247 S$. hyicus, 218 S. chromogenes, $291 S$. sciuri, 123 S. saprophyticus, 119 S. epidermidis, 114 S. xylosus, 93 S. cohnii, 88 S. haemolyticus, 39 S. hominis, 37 S. warneri, 22 S. simulans, 18 S. gallinarum, 15 S. caprae, 12 S. equorum, 11 S. lentus, 11 
S. arlettae, 9 S. kloosii, 3 S. carnosus and 3 S. auricularis. Moreover, 141 Micrococcus spp. were also used without attempting to classify individual strains. All the above strains were isolated from clinically healthy animals.

\section{Indicator Strains}

The set of indicator strains consisted of $S$. aureus Mau 124/89, S. aureus Mau 125/89, S. haemolyticus M68/89, S. epidermidis M 66/89 and S. warneri M71/89 as producers of staphylococcal delta hemolysin, and also of $S$. aureus Mau $126 / 89$ as a producer of staphylococcal beta hemolysin. These strains are stored under their corresponding designations in the Czechoslovak National Collection of Type Cultures (CNCTC) in Prague.

\section{Staphylococcal beta hemolysin}

For the preparation of a pre-purified form of staphylococcal beta hemolysin produced by the strain $S$. aureus Mau 126/80, we used a previously desgribed modification (Skalka et al. 1979a; $1979 b$ ) of the extraction by acetone (Haque and Baldwin 1969).

Hemolytic interactions

Hemolytic antagonism and synergism were studied using routine methods of cultivation lines of the strains tested leading perpendicularly to the growth lines of indicator strains on blood agars.

\section{Results}

The first series of experiments was made on agars with human erythrocytes. After 24-hour incubation, all delta hemolysin producing indicator strains formed a wide zone of complete hemolysis on these media. This hemolysis was clearly inhibited if delta hemolysin producers were simultaneously cultivated with strains $S$. hyicus and $S$. chromogenes. The inhibition zone was triangular in shape, with its top pointing towards the delta strain cultivation line. This was observed not only at that side of the indicator strain line where the tested strain grew but also on the opposite side where the strain tested was not cultivated (Fig. 1). In already 24 hours, some strains of $S$. hyicus and $S$. chromogenes began to manifest signs of their own direct hemolysis, which, however, was fully manifested only after another 24 hours of incubation. The described effect of hemolytic antagonism was produced by all strains of $S$. hyicus and $S$. chromogenes.

In the second series of experiments, blood agar with sheep erythrocytes was used. Hemolytic zones around cultivation lines of delta producers were much narrower than on media with human erythrocytes, but they were also clearly inhibited by all strains of $S$. hyicus and $S$. chromogenes. Antagonistic effects were similar to inhibition effects observed on media with human erythrocytes, their triangular shape was, however, much flatter (Fig. 2). The intensity of delta hemolysis inhibition of coagulase-negative strains exceeded the analogous inhibition observed in coagulase-positive strains.

In the third series of experiments, the indicator system exploited a potentiation of the intensity of delta hemolysin in the zone of staphylococcal beta hemolysin on media with sheep erythrocytes. The beta hemolysin producing strain and the delta hemolysin producer were cultivated parallelly close to each other and cultivation lines of $S$. hyicus and $S$. chromogenes were set perpendicular to otheir lines. All strains of the species studied inhibited the hemolytic effect of delta hemolysin potentiated in the beta hemolysin zone, but manifested no hemolytic interaction with staphylococcal beta hemolysin (Fig. 3).

In the fourth series of experiments, a modification of the method from the third series was used. The beta hemolysin producer was substituted with a pre-purified non-cellular form of its staphylococcal exosubstance and this was. 


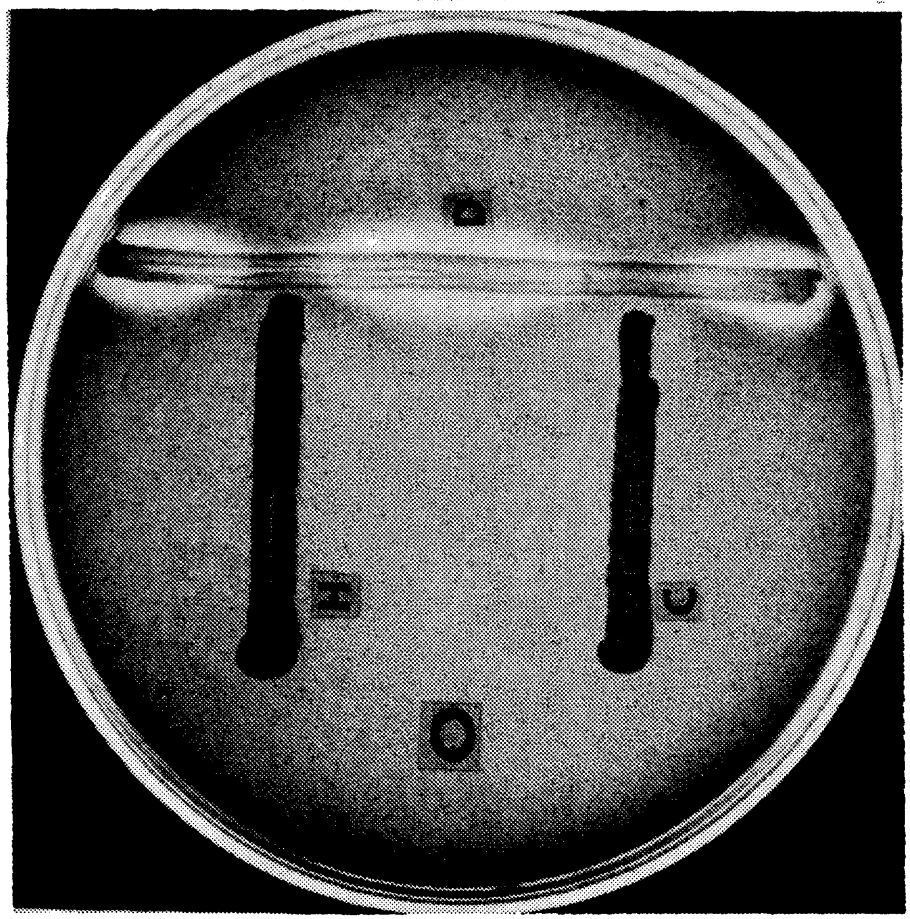

ㅇํㅇ월

ฐัญ

范

혼

ن

छ

ธี ธี

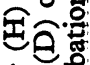

资

론.

以

पू छ

迩战

幽出岩

.

西品

음

完要

八岛

贯

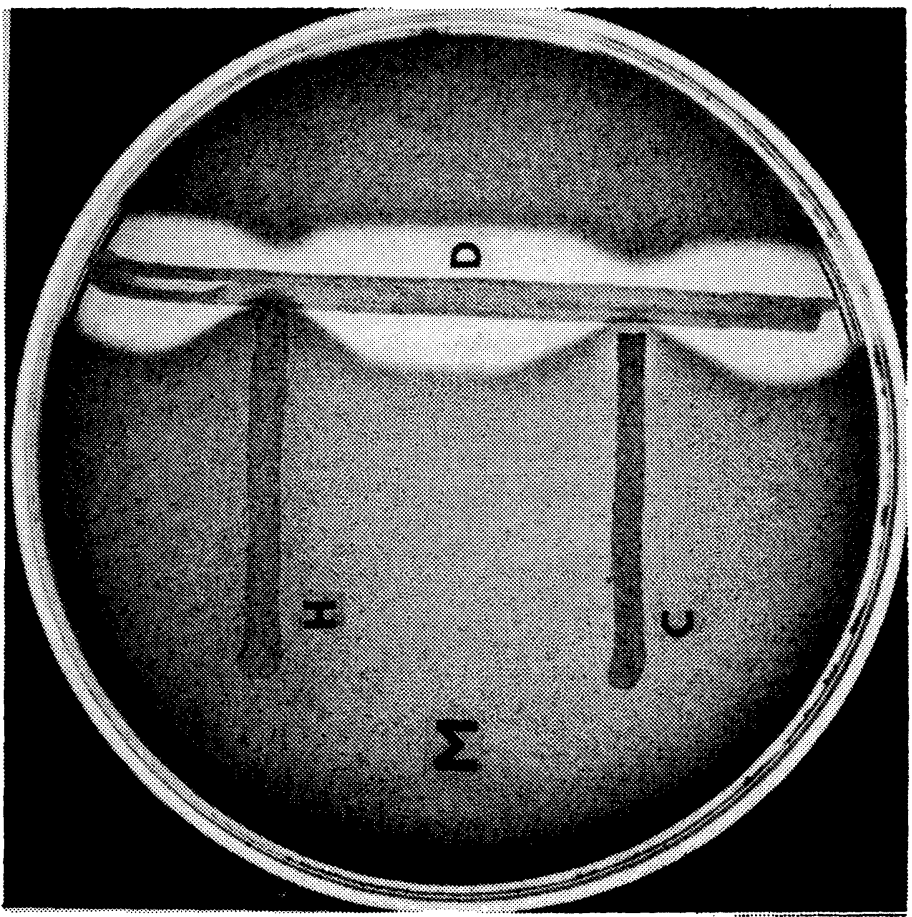

뎡 혹

తิ

ई

요

s.

डै

v

ซ ธี่

สิอ.

金奉

况

. 족저

इै है

的密

㟧的疋

获岁

造

. ్ㅠ.

중

范

엉

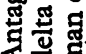

दे हू

-

完 


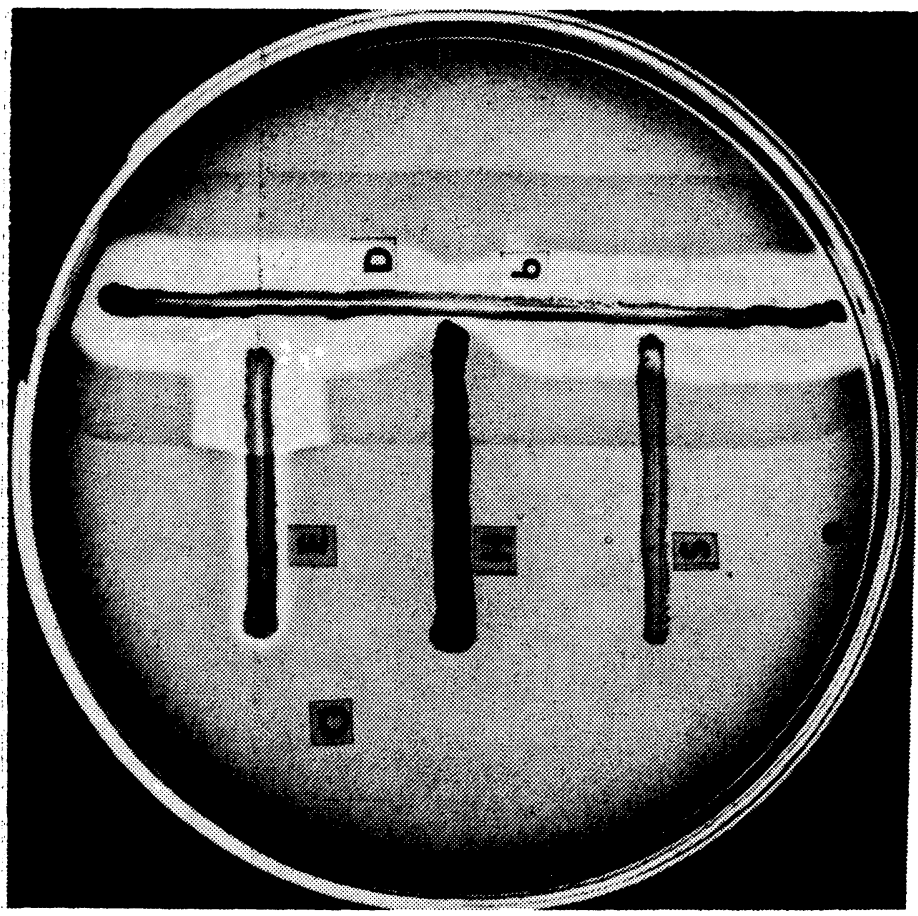

क.

모ㅇㅕㅕ

. 붕山氞

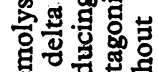

\&

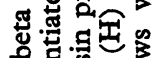

式冬

앰영.

ช્ठ웛

鸟山

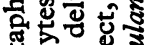

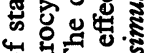

出教

อ客察的

造

. 过骂

응 돈

क्ञ 귱

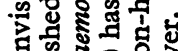

与 国国

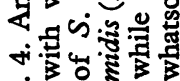

in

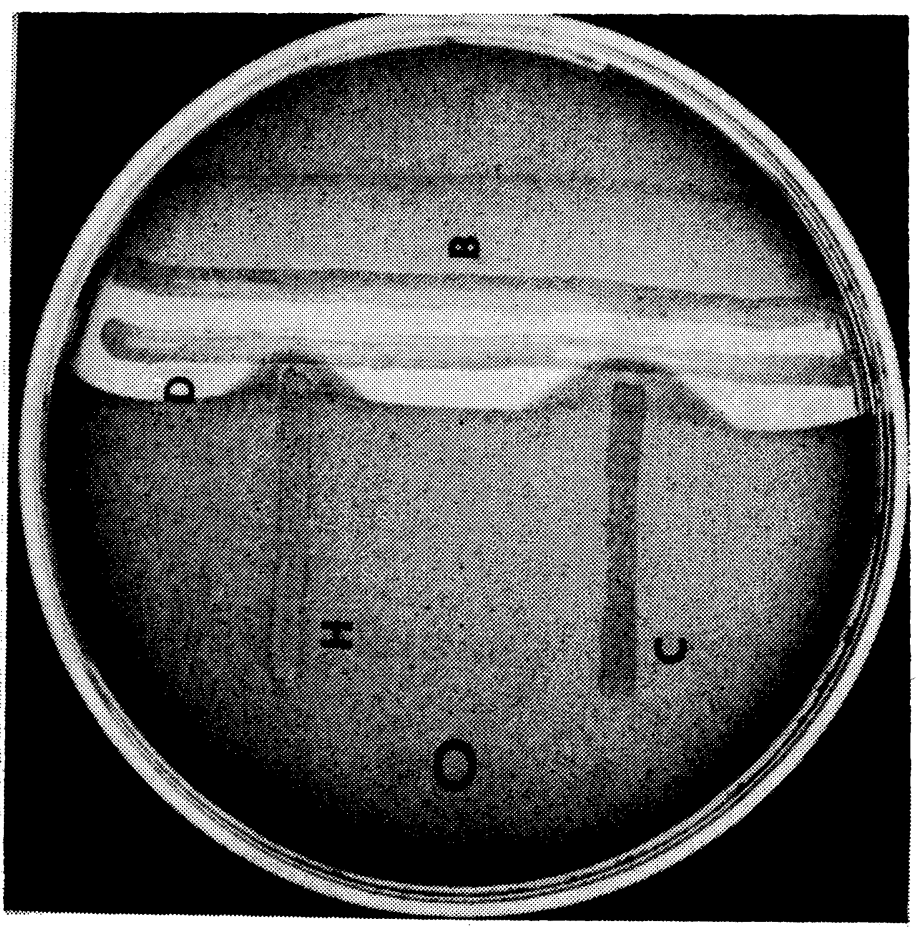

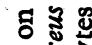

త

ঐ通

홍응

홍 웡

ง.

的苞

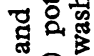

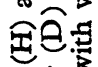

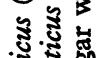

ลิ

ต옹뎡

岁氞解

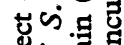

悹㟧焉

공동

증 청

으의

莺氙

ห่

$\dot{0}$ 
applied as a line on the agar medium with erythrocytes. The delta hemolysin producer was cultivated directly on the beta hemolysin line immediately after it was applied on the medium. The strains studied were again streaked perpendicular to the line of the indicator complex. In this experimental series, all strains of staphylococci and micrococi used in the present study were examined. Strains $S$. hyicus and $S$. chromogenes inhibited complete hemolysis of delta hemolysin potentiated by pre-purified staphylococcal beta hemolysin. Similar although less intensive effect of hemolytic antagonism was also observed in a majority of strains $S$. sciuri $(85 \%), S$. lentus $(73 \%)$ and the micrococci tested $(89 \%)$. The other strains of staphylococci used were divided into two groups. In the beta hemolysin zone, which exceeded synergic hemolysis of the indicator delta strain, the strains with their own production of delta hemolysin manifested a well-defined reaction of their own hemolytic synergism, whole strains with a negative hemolysin production grew with no effect of hemolytic interaction whatsoever (Fig. 4). A summary of the results obtained is given in Table 1.

Table 1

Results of the combined test of hemolytic interactions between staphylococci

\begin{tabular}{|c|c|c|c|c|}
\hline Staphylococcus & No. of strains & $\begin{array}{c}\text { Inhibition of delta } \\
\text { hemolysin }\end{array}$ & $\begin{array}{l}\text { Synergism in beta } \\
\text { hemolysin zone }\end{array}$ & No effect \\
\hline $\begin{array}{l}\text { hyicus } \\
\text { chromogenes }\end{array}$ & $\begin{array}{l}247 \\
218\end{array}$ & $\begin{array}{l}247 \\
218\end{array}$ & $\begin{array}{l}0 \\
0\end{array}$ & $\begin{array}{l}0 \\
0\end{array}$ \\
\hline $\begin{array}{l}\text { sciuri } \\
\text { lentus }\end{array}$ & $\begin{array}{r}129 \\
11\end{array}$ & $\begin{array}{r}110 \\
8\end{array}$ & $\begin{array}{l}\mathbf{0} \\
\mathbf{0}\end{array}$ & $\begin{array}{r}19 \\
3\end{array}$ \\
\hline $\begin{array}{l}\text { saprophyticus } \\
\text { epidermidis } \\
\text { xylosus } \\
\text { cohnii } \\
\text { haemolyticus } \\
\text { hominis } \\
\text { warneri } \\
\text { simulans } \\
\text { galli narum } \\
\text { caprae } \\
\text { capitis } \\
\text { equorum } \\
\text { arlettae } \\
\text { kloosii } \\
\text { carnosus } \\
\text { auricularis }\end{array}$ & $\begin{array}{r}123 \\
119 \\
114 \\
93 \\
88 \\
39 \\
37 \\
22 \\
18 \\
15 \\
13 \\
12 \\
11 \\
9 \\
3 \\
3\end{array}$ & $\begin{array}{l}0 \\
0 \\
0 \\
0 \\
0 \\
0 \\
0 \\
0 \\
0 \\
0 \\
0 \\
0 \\
0 \\
0 \\
0 \\
0\end{array}$ & $\begin{array}{r}33 \\
106 \\
81 \\
52 \\
62 \\
31 \\
35 \\
19 \\
10 \\
9 \\
8 \\
3 \\
6 \\
6 \\
0 \\
1\end{array}$ & $\begin{array}{r}90 \\
13 \\
33 \\
41 \\
26 \\
8 \\
2 \\
3 \\
8 \\
6 \\
6 \\
5 \\
9 \\
5 \\
3 \\
3 \\
2\end{array}$ \\
\hline Micrococcus sp. & 141 & 126 & 0 & 15 \\
\hline
\end{tabular}

\section{Discussion}

Identification of staphylococcal hemolysins on blood agars with washed erythrocytes of ruminants, and sheep in particular, depends on the existence of antagonism between hemolysins alpha and beta, synergism between hemolysins beta and delta and also on the fact that hemolysins alpha and delta or hemolysins of the same type do not influence each other (Adamczyk \& Blaurock 1963; Mayer 1966; Skalka et al. 1979a, 1979b; Lammler \& Blobel 1987). The response of the hemolysin produced by coagulase-negative species of staphylococci is identical to that of delta hemolysin of coagulase-positive staphylococci 
and this problem of identity (Turner \& Pickard 1979) or heterogeneity (Wad-strom \& Rozgonyi 1986) of the two substances has not been resolved satisfactorily. In view of the identity of direct and synergic hemolytic effects observed in both of the substances mentioned, we use the term delta hemolysin also for the product of coagulase-negative staphylococci in agreement with other authors (Hebert \& Hancock 1985; Scheifele \& Bjornson 1988).

On media with sheep erythrocytes, the previously observed direct hemolytic activity of $S$. hyicus and $S$. chromogenes on agars with rabbit or human erythrocytes was found neither direct or synergistic with beta hemolysin (Skalka 1988). On those blood agars where a direct hemolytic effect of $S$. hyicus and $S$. chromogenes was observed, its inhibition by staphylococcal alpha-antihemolysin was unsuccessful (unpublished data). Our results excluded any possible similarity between hemolytic exosubstances of the above types and staphylococcal hemolysins alpha and delta, as well as any similarity with gamma hemolysin (Goodfellow et al. 1987), which is inhibited by agar (Jackson 1962).

Synergism of staphylococcal alpha and delta hemolysins was described (Christie \& Graydon 1941) earlier than the classical CAMP test (Christie et al 1944) and the importance of its detection has been stressed recently (Boyce 1985; Hebert \& Hancock 1985; Lammler \& Blobel |1987; Watts \& Owens 1987; Hebert et al. 1988). A direct hemolytic effect of delta hemolysin is inhibited both non-specifically by lipoproteins of blood serum (Jackson \& Little 1958; Whitelaw \& Birkbeck 1978) and by a specific antibody (Turner \& Pickard 1979). Isolated data on the inhibition of delta-hemolysin activity of coagulase-positive as well as coagulase-negative staphylococci by an non-hemolysing exoprotein of certain micrococcal strains on agars with human erythrocytes (Liu 1954) were never successfully reproduced (Flamm 1957) and this. may explain why this information fell into oblivion.

In view of our previous negative results with tests of hemolytic interaction. between $S$. hyicus and $S$. chromogenes and staphylococcal beta and alpha hemolysins, we were particularly anxious to ascertain any possible interactions of these two species of staphylococci with delta-hemolysin producing staphylococci. First tests were made on media with human erythrocytes, which are highly sensitive to delta hemolysin (Marks \& Vaughan 1950; Jeljaszewicz 1972; Wiseman 1975) but scarcely sensitive to the hemolytic activity of the two species studied (Skalka 1988). The antagonistic effect ascertained in the first test series resembled the description of delta-hemolysin inhibition by strains of micrococci ( $\mathrm{Liu}$ 1954). It was, however, already demonstrated after 24 hours with a simultaneous cultivation of tested and indicator strains, and did not require the 24-hour pre-cultivation of antagonistic strains described by the author cited. The second series of our tests proved the existence of this antagonist also on media with sheep erythrocytes. The differences observed between the intensity of inhibition in coagulase-negative and coagulase-positive producers of delta hemolysin can be explained by the fact that most of the coagulase-positive staphylococci also produce certain amounts of alpha hemolysin, practically undetectable by routine methods (Arbuthnott et al. 1973; Wiseman 1975; Murphy \& Hague 1980).

The methods used in the third series of our tests set off the hemolysis of delta strains and thus also the effect of antagonism on the media with sheep erythrocytes, but it allowed the extension of total hemolysis only on one side of the cultivation line of the delta producer. We therefore made use of our previous 
experience (Skalka et al. 1979a, 1979) and the beta hemolysin producer was replaced with a pre-washed form of this exosubstance. This modification resulted in a uniform extension of the total hemolysis zone along both sides of the cultivation line of the delta-hemolysin producer. The effective zone of staphylococcal beta hemolysin always exceeded the zone of total hemolysis, which also allowed detection of any delta hemolysin produced by the staphylococcal strain examined. Because it is particularly suitable for a detection of hemolytic antagonism as well as synergism of staphylococcal hemolysins, we called this modification of the combined test of hemolytic interactions (CTHI).

Besides testing $S$. hyicus and $S$. chromogenes, the combined test of hemolytic interactions was used in the fourth test series also for an examination of 859 strains of coagulase-negative staphylococci and 141 strains of micrococci. Delta hemolysin antagonism; although less intensive than in the case of strains $S$. hyicus and S. chromogenes, was demonstrated in a majority of strains $S$. sciuri, $S$. lentus and Micrococcus spp. Similar antagonism was observed in none of the other 719 strains representing 16 species of coagulase-negative staphylococci but production of delta hemolysin was demonstrated in 462 of them. Our finding of antagonistic activity of micrococci is in agreement with existing information (Liu 1954), while the antagonism of $S$. hyicus, $S$. chromogenes, $S$. sciuri and $S$. lentus has not been described before. We believe that the demonstration of antagonism is a useful complementary test for the diagnosis of the species mentioned and particularly for detecting $S$. hyicus and $S$. chromogenes.

\section{Antagonický efekt Staphylococcus hyicus a Staphylococcus chromogenes na stafylokokový delta hemolyzin}

Staphylococcus hyicus a Staphylococcus chromogenes maji schopnost inhibovat hemolytický efekt stafylokokového delta hemolyzinu na agarových médiích suplementovaných lidskými nebo ovčími erythrocyty. Tato inhibice se uplatñuje i tehdy, když je účinek delta hemolyzinu na agarech s ovčími erytrocyty potencován stafylokokovým beta hemolyzinem. Podobný, i když slaběji vyjádřený, antagonický efekt na stafylokokový delta hemolyzin má i většina kmenů Staphylococcus sciuri, Staphylococcus lentus a Micrococcus spp. Ostatní druhy koaguláza negativních stafylokoků nemají antagonistický účinek na delta hemolyzin. Byla předložena technika kombinovaného testu hemolytických interakcí (KTHI) pro simultánní průkaz hemolytického antagonismu a synergismu, kterou lze diferencovat $S$. hyicus a $S$. chromogenes od ostatnich novobiocin senzitivních stafylokokových druhů.

\section{Антагонистический эффект \\ Staphylococcus hyicus и Staphylococcus chromogenes на стафилококковый дельта-гемопизин}

Staphylococcus hyicus и Staphylococcus chromogenes отличаются свособностью к ингибированию гемопитического эффекта стафилококкового дельта-гемолизина на агаровой среде, дополненной эритроцитами человека или овцы. Данное торможение имеет место даже тогда, когда воздействие депьта-гемолизина на агарах с овечьими эритроцитами потенцировано стафилококковым бета-гемолизином. Аналогич- 
ным, хотя и не столь выразительным антагонистическим эффектом на стафилококковый депьта-гемолизин отличается также большинство штаммов Staphylococcus sciuri, Staphylococcus lentus и некоторые Micrococcus spp. Остальные виды коагулаза-отрицательных стафилококков не отличаются антагонистическим воздействием к дельта-гемолизину. Была представлена техника комбинированного теста гемолитических взаимодействий (СТHI) для синхронного определения гемолитического антагонизма и синергизма с помощью которой можно дифференцировать S. hyicus и S. chromogenes от остальных чүвствительных к новобиоцину стафилококковых видов.

\section{References}

ADAMCZYK, B.-BLAUROCK, G.: Zum Nachweis spezifischer Staphylokokkenhämolysine. Z. ges. Hyg., 9, 1963: 456-471

ARBUTHNOTT, J. P.-FREER, J. H.-McNIVEN, A. C.: Physical properties of staphylococcal alpha toxin and aspects of alpha-toxin membrane interactions. p. 285-297. In: JELJASZEWICZ, J. (ed.): Staphylococci and staphylococcal infections. S. Karger. Basel, München, Paris, London, New York, Sydney. 1973. 658 p.

BOYCE, J. M.: Detection of synergistic hemolytic activity of Staphylococcus aureus with the Cathra replicator. J. Clin. Microbiol., 21, 1985: 835-837

CHRISTIE, R.-ATKINS, N. E.-MUNCH-PETERSEN, E.: A note on a lytic phenomenon shown by group B streptococci. Aust. J. Exp. Biol. Med. Sci., 22, 1944: 197-200

CHRISTIE, R.-GRAYDON, J. J.: Observations on staphylococcal hemolysins and staphylococcal lipase. Aust. J. Exp. Biol. Med. Sci., 19, 1941: 9-16

DOLMAN, C. E.: Pathogenic and antigenic properties of Staphylococcus toxin. Can. J. Publ. Hlth., 23, 1932: 125-132

FLAMM, H.: Zonenhämolyse, Hämolysesteigerung und Hämolysehemmung bei Staphylokokken. Schweiz. Z. Path. Bakt., 20, 1957: 358-373

GLENNY, A. T.-STEVENS, N. F.: Staphylococcus toxins and antitoxins. J. Pathol. Bacteriol., 40, 1935: $201-210$

GOODFELLOW, M.-HARWOOD, C. R.-NAHAIE, M. R.: Impact of plasmids and genetic change on the numerical classification of staphylococci. Zbl. Bakt. Hyg. A 266, 1987: $60-85$

HAQUE, R. U.-BALDWIN, J. N.: Purification and properties of staphylococcal beta hemolysin. II. Purification of beta hemolysin. J. Bacteriol., 100, 1969: 751 -759

HÉBERT. G. A.-COOKSEY, R. C.-CLARK, N. C.-HILL, B. B.-JARWIS, W. R.THORNSBERRY, C.: Biotyping coagulase-negative staphylococci. J. Clin. Microbiol., 26, 1988: $1950-1956$

HÉBERT, G. A.-HANCOCK, G. A.: Synergistic hemolysis exhibited by species of staphylococci. J. Clin. Microbiol., 22, 1985: 409-415

JACKSON, A. W.: Staphylococcal gamma-lysin and its differentiation from delta-lysin. VIIIth Int. Congr. Microbiol., Abstracts, 1962: 111

JACKSON, A. W.-LITTLE, R. M.: Staphylococcal toxins. II. Factors affecting hemolysis by delta-lysin. Can. J. Microbiol., 4, 1958: 435-444

JELJASZEWICZ, J.: Toxins (Hemolysins). p. 249-280. In: COHEN, J. O. (ed.): The staphylococci. Wiley-Interscience. New York. 1972. $548 \mathrm{p}$.

LÄMMLER, C.-BLOBEL, H.: Synergistische und antagonistische hämolytische Reaktionen bakterieller Proteine. Berl. Münch. Tierärztl. Wsch., 100, 1987: 95-99

LIU, P.: Inhibition of a staphylococcal hemolysin by a soluble substance produced by a nonhemolytic Micrococcus species. J. Bacteriol., 68, 1954: 718-723

MARKS, J.-VAUGHAN, A. C. T.: Staphylococcal delta haemolysin. J. Pathol. Bacteriol., 62, 1950: $597-615$

MEYER, W.: Differenzierungschema für Standard-Varietäten von Staphylococcus aureus. Zbl. Bakt. Hyg. I. Orig. 201, 1966: 465-481

MURPHY, R. A. - HAQUE, R.: Partitioning of staphylococcal delta haemolysin. J. Med. Microbiol., 13, 1980: 193-200

SCHEIFELE, D. W.-BJORNSON, G. L.: Delta toxin activity in coagulase-negative staphylococci from the bowels of neonates. J. Clin. Microbiol., 26, 1988: 279-282 
SKALKA, B.: Hemolytic activity of Staphylococcus hyicus and Staphylococcus chromogenes. Acta vet. Brno, 57, 1988: 3-11

SKALKA, B. - SMOLA, J. - PILLICH, J.: Diagnostic utilization of hemolytically active exosubstances of certain Gram positive bacteria. I. Detection of staphylococcal hemolysins with prepurified preparations of staphylococcal beta-toxin and CAMP-factor of Streptococcus agalactiae. J. Hyg. Epidemiol. Microbiol. Immunol. (Prague), 23, 1979a: 407-416

SKALKA, B.-SMOLA, J. - PILLICH, J.: Simple method of detecting staphylococcal hemolysins. Zbl. Bakt. Hyg., I. Abt. Orig. A 245, 1979b: 283-286

SMITH, M. L.-PRICE, S. A.: Staphylococcus gamma haemolysin. J. Pathol. Bacteriol., 47, 1938: $379-393$

TURNER, W. H.-PICKARD, D. J.: Immunological relationship between delta-hemolysins of Staphylococcus aureus and coagulase-negative strains of staphylococci. Infect. Immun., 23, 1979: $910-911$

WADSTRÖM, T.-ROZGONYI, F.: Virulence determinants of coagulase-negative staphylococci. p. 123-130. In: MARDH., P. A.-SCHLEIFER, K. H. (ed.): Coagulase-negative staphylococci. Almquist and Wiksell. Stockholm. 1986. 222 p.

WATTS, J. L.-OWENS, W. E.: Synergistic hemolysis associated with coagulase-negative staphylococci isolated from bovine mammary glands. J. Clin. Microbiol., 25, 1987: 2 037-2 039

WHITELAW, D. D. - BIRKBECK, T. H.: Inhibition of staphylococcal delta haemolysin by human serum lipoproteins. FEMS Microbiol. Letters, 3, 1978: 335-338

WILLIAMS, R. E. O.-HARPER, G. J.: Staphylococcal haemolysins on sheep blood agar with evidence for a fourth haemolysin. J. Pathol. Bacteriol., 59, 1947: 69-78

WISEMAN, G. M.: The hemolysins of Staphylococcus aureus. Bacteriol. Rev., 39, 1975: 317-344 